\title{
Can the History of Communication and Media Research Proceed without the Philosophy of Technology?
}

\section{Filipa Subtil (iD}

ICNova and Instituto Politécnico de Lisboa, fsubtil@escs.ipl.pt

Historians OF COMMUNICATION and media studies have never been very interested in technology, but surely there is thinking about technology in media studies, even if it is not often explicit. Consider the case of uses and gratifications research as developed by Herta Herzog and later elaborated by Elihu Katz, which tended to regard psychological and sociological variables as real and primary, and the media as a second-hand factor and manifestation of those variables. Does this approach not contain the assumption that media technologies are merely technical things used to accomplish certain ends? And consequently, that these things are value-neutral-that technological objects do not play a primary role in culture? Consider the case of Harold A. Innis: Does he deserve the pejorative "technological determinist" for emphasizing that the specific technological characteristics of a prevalent medium in a given society condition the social practices of communication, institutions, and systems of social organization and power? ${ }^{1}$ Is it plausible to think that certain technologies might themselves have political properties?

And how to evaluate the approach of the technische Medien of Friedrich A. Kittler, as he writes in the preface to Gramophone, Film, Typewriter that the "media determine our situation" and "what remains of people is what media can store and communicate"? ${ }^{2}$ Should we take his thesis that our knowledge is critically dependent on the cultural techniques we invent? These questions have been hanging over the history of communication and media research for a long time. They have become even more pressing with the emergence
Filipa Subtil, "Can the History of Communication and Media Research Proceed without the Philosophy of Technology?," History of Media Studies 1 (2021), https://doi.org/ 10.32376/d895aoea.dab6ca65.

\footnotetext{
${ }^{1}$ Harold A. Innis, Empire and Communications (Toronto: University of Toronto Press, 1970); Harold A. Innis, The Bias of Communication (Toronto: University of Toronto Press, 1999).

${ }^{2}$ Friedrich A. Kittler, Gramophone, Film, Typewriter (Stanford, CA: Stanford University Press, 1999), xxxix.
} 
of computer networks, digitalization, and digital algorithmic calculation devices.

This essay is based on the observation that, while many philosophers and theorists of technology are studying the media and importing ideas from media studies into the philosophy of technology, ${ }^{3}$ historians of media studies have not granted enough attention to the question of technology. A rare exception was a recent forum organized by Lana Rakow in Journalism \& Mass Communication Quarterly. 4 The fact is that historians of media and communication research have not grappled with the ideological and philosophical assumptions around technology that are present in the work of the field's major historical figures. I contend that we must start a dialogue with the philosophy of technology, and with the social studies of science and technology, in order to analyze the discipline's unconscious and embedded presuppositions about the relationship between technology and media. Looking for other ways to question technology could pave the way for research that is historical and theoretically founded on the structural transformations of communication in the modern era.

With this prospect in mind, I present notes that lead to a reflection about the history of communication and media studies, and future paths for research, which draws on the contributions that philosophers of technology have made to thinking about media technologies. In these notes, I focus on two crucial problems: (1) definitions of technology and (2) the modern relationship between myth/utopia and communication technologies.

\section{Defining Technology: Derivative Agent? Central Actor? Trickster?}

The definition of technology most deeply rooted in modern life is that technologies are means to free human beings from their limitations and to positively transform human life. They are instruments, tools, artifacts, things to accomplish desired ends. Admittedly, technical objects can be used for good or for evil, but it is their use that may be improper, not the instrument, tool, or artifact itself. According to this perspective, technology is a value-neutral human product. There is no reason to question technology, but only its use, or at most, the context in which it is submersed. This notion has accompanied the modern world's bet on the expansion of technological capacity. This expansion-that is, an increase in human power-has been viewed as a necessary condition for humans to solve the most diverse problems and even to establish a materially abundant and harmonious society. It is part of the modern belief in Progress, a

\author{
${ }^{3}$ Among others, see Günther Anders, \\ "The World as Phantom and as Matrix," \\ Dissent 3, no.1 (1956); Langdon Winner, \\ "Mythinformation," in The Whale and \\ Reactor: A Search for Limits in an Age of \\ High Technology (Chicago: University of \\ Chicago Press, 1989); Albert Borgmann, \\ Holding On to Reality: The Nature of \\ Information at the Turn of the Millennium \\ (Chicago: University of Chicago Press, \\ 1999); Pierre Musso, Télécommunications \\ et Philosophie des Réseaux (Paris: PUF, \\ 1997); Pierre Musso, Critique des Réseaux \\ (Paris: PUF, 2003); and Don Ihde, \\ Listening and Voice (Albany: State \\ University of New York Press, 2007). \\ ${ }^{4}$ Lana Rakow, ed., "Philosophy of \\ Technology: Who is in the Saddle?" \\ (Invited Forum), Journalism \& Mass \\ Communication Quarterly 96, no. 2 \\ (2019). The forum is composed of short \\ texts authored by Lana Rakow, Jeremy \\ Swartz, Carolyn Marvin, Robert K. \\ Logan, and Beth Coleman.
}


collective mentality that understands History as a record of the improvement of the conditions of human life. 5

The conception of technology as a means is implicit in many studies based on the analysis of the uses and appropriations of the media and, to some extent, their effects. In truth, it must be recognized that technology develops by interacting with social and economic processes and forces. It is also undeniable that different uses or appropriations of media and technologies exist. The same point can be made about the effects of technologies, which may be driven by users' utilization or social policies. Without a doubt, it is the sociological milieu of the audience which conditions the use of media, and human perception is an active process of organization and structuring. But analysis of use, as a method, is fundamentally blind to the cultural (as opposed to merely sociological) nature of human life. That is to say, humans have a basic cultural disposition to filter experiences in symbolic forms, as Clifford Geertz ${ }^{6}$ and the tradition of cultural studies has clarified so well. To this shortcoming we add another: If this approach to analysis based on uses and effects has tended to be reductionist because it does not recognize the central place that culture occupies in the life of symbolic beings, it has also tended to be reductionist because it has not understood technology (material culture) as an actor itself, a means and also an end.

In philosophical thinking about technology, Langdon Winner has been a prominent voice in rejecting the exaggerated application of the social determinist perspective. 7 Instead of reducing technical artifacts to the interaction of social forces, he has urged that attention be paid to the characteristics of technical objects and to the significance of those characteristics. He sees his thinking in connection with the philosophical precept of Edmund Husserl, of returning to things, and combines that principle with influences from Ludwig Wittgenstein, Karl Marx, Lewis Mumford, and Jacques Ellul. In 1986, Winner argued that artifacts can contain political properties and that technologies enhance "forms of life." He provided various examples to show that certain technologies were prepared beforehand to favor certain social interests and patterns of power. ${ }^{8}$ More than three decades later, this idea is very evident when we realize that, for example, fossil fuels and green energies are articulated with very different values and interests-or even when we realize the biases of the algorithms that guide us in many decisions through an infrastructure of calculations. It is also more evident today that societies can choose technological structures that can, in turn, variously influence the ways of working, traveling, consuming, communicating, and deciding.

Another thinker about technology, Carl Mitcham, distinguishes two ways, two ideal types, of thinking about technology and its re-
${ }^{5}$ Leo Marx, "The Domination of Nature and the Redefinition of Progress," in Progress: Fact or Illusion, ed. Leo Marx and Bruce Mazlish (Ann Arbor: University of Michigan Press, 1996).

${ }^{6}$ Clifford Geertz, The Interpretation of Cultures (New York: Basic Books, 1973).
${ }^{8}$ See Langdon Winner, "Do Artefacts Have Politics?" in The Whale and Reactor: A Search for Limits in an Age of High Technology (Chicago: University of Chicago Press, 1989). 
lation to human life in general. There is, first, the engineering approach, which sees technology as the core of what it is to be human, and therefore sees no problem with the expansion of technology into all areas of life. The second approach is the humanities-rooted philosophy of technology, which asserts there are other legitimate forms of knowing, acting, and being in the world, other than the technological sort. ${ }^{9}$ Mitcham, who is versed in both engineering thought and thinkers such as Martin Heidegger, José Ortega y Gasset, and Ivan Illich, defends a complex notion of technology and maintains that it has four dimensions: object, knowledge, activity, and volition. Thus, technology is a mere thing, but it is also a thing to think with, a thing to act with, and a thing that influences the shape of culture. For both Winner and Mitcham, a value-neutral vision of technology prevents its inscription in culture, its critical analysis, and leads to the neglect of the intentions-the social, economic and political interests-of those who design, develop, finance, and control it.

We find these definitions of technology in the work of media theorist James W. Carey, who writes that technology is more than a "group of purposeful instruments"; they are "things that shape the self and the mind," that "serve as instruments of action."10 He emphasizes that in all industrial societies, and particularly in the US, technology is "also the central character and actor in our [North Americans'] social drama, and an end as well as a means."11 Moreover, Carey goes as far as to say that technology "plays the role of the trickster in American culture,"12 given that machines are not only believed to "make history," but they also "play ... the role of a superlegislator with a dominating voice in the conversation of the culture."13 Could Carey's communication-as-culture approach be inserted into the tradition that Mitcham calls the philosophy of technology in the humanities? It should be noted that Carey, whose relationship with the work of Innis was not a marriage of convenience, defended in his famed 1983 essay on the telegraph the claim that a thorough treatment of the consequences of that instrument would demonstrate that it altered the spatial and temporal boundaries of human interaction and brought about new forms of language, ordinary knowledge, structures of social relations, and economic and political power. ${ }^{14}$ In turn, we can ask whether and to what extent the engineering perspective of technology, as defined by Mitcham, may be unconsciously incorporated into the thinking of communication and media research that, contrary to Carey, does not consider technology as a cultural and political force and thus undermines the neutral vision of technology. In order to understand the media, is the philosophy of technology necessary?

History of Media Studies, vol. 1, 2021
${ }^{9}$ Carl Mitcham, Thinking through Technology: The Path between Engineering and Philosophy (Chicago: University of Chicago Press, 1994).

${ }^{10}$ James W. Carey, "Afterword: The Culture in Question," in James W. Carey. A Critical Reader, ed. Eve Stryker Munson and Catherine A. Warren (Minneapolis: University of Minnesota Press, 1997), 316.

${ }^{11}$ Carey, "Afterword," 316.

${ }^{12}$ Carey, "Afterword," 316.

${ }^{13}$ Carey, "Afterword," 317.
${ }^{14}$ James W. Carey, "Technology and Ideology: The Case of the Telegraph," in Communication as Culture. Essays on Media and Society, Rev. Ed. (New York: Routledge, 2009). See also, Filipa Subtil, “Du Télégraphe à Internet: Enjeux Politiques Liés au Technologies de l'Information," in La Contribution en Ligne. Pratiques Participatives à l'Ére $d u$ Capitalisme Informationnel, eds. Serge Proulx, José L. Garcia, and Lorna Heaton (Montreal: Les Presses d'Université du Québec, 2014). 


\section{The Question of the Demythologization of the Technological-Communicational}

\section{Utopia}

The relationship between communication technologies, myth, and utopia is another major topic in the question of technology. Social reality is not only composed of what is in force, but also by hopes, ideas, myths, and utopias-and technology in the modern world has appeared as the necessary resource for the achievement of the continued improvement of human life and the social world. In The Prophets of Paris, the historian Frank E. Manuel shows us how Turgot, Condorcet, Saint-Simon, Fourier, Comte, and their followers were heralds of Progress as an idealization of perfectible societies and had solutions for the ills and problems of a wretched mankind. ${ }^{15}$ Saint-Simon, one of Marx's utopian socialists and one of his inspirations, was inclined toward a Promethean and technocratic version of Progress. In France, the philosopher Pierre Musso has distinguished himself for arguing that the imaginary of the Internet and cyberculture go back to the great Saint-Simonian utopian project of universal interconnection made possible by technologies. ${ }^{16}$ In the US, Leo Marx pointed to the interactions between culture, utopia, and technology after the waning of the country's pastoral self-image through the concept of "technological sublime." Carey followed this lead and appropriated this concept in the two texts he wrote with John J. Quirk ${ }^{17}$ for "a project of de-mystification," as Jefferson Pooley ${ }^{18}$ clarified, of the sublime electronic rhetoric as an ideology of the future. To demythologize the computer revolution was also Winner's purpose in "Mythinformation."19 More recently, Vincent Mosco proposed the expression "digital sublime" in order to dismantle the myths and power of cyberspace. ${ }^{20}$

However, we actually find the most robust tradition of demystifying the technological-communicational utopia in a vast gallery of French media theorists. Lucien Sfez, ${ }^{21}$ who was Pierre Musso's doctoral dissertation adviser, took decisive steps on a path that includes Armand Mattelart, ${ }^{22}$ Philipe Breton, ${ }^{23}$ Patrick Flichy, ${ }^{24}$ and Dominique Cardon. ${ }^{25}$ These theorists steer away from the cybernetic tradition of Norbert Wiener regarding the supposed similarity between nervous systems and electronic machines; from the "network society" of Manuel Castells, where the logic of a network is the new social morphology of societies, ${ }^{26}$ and from the image of the Internet as a "collective intelligence," "thinking network," or "planetary brain" of Pierre Lévy. ${ }^{27}$ Among the cited French theorists, we find one of the most systematic attempts to delegitimize the technological utopias of communication. They accentuate and at the same time call into question the fascination that these utopias have been able
${ }^{15}$ Frank E. Manuel, The Prophets of Paris (New York: Harper Torchbooks, 1962). See also Frank E. Manuel and Fritzie P. Manuel, Utopian Thought in the Western World (Cambridge, MA: Harvard University Press, 1979).

${ }^{16}$ Pierre Musso, Télécommunications et Philosophie des Réseaux (Paris: PUF, 1997); Pierre Musso, Critique des Réseaux (Paris: PUF, 2003); and Pierre Musso, dir. Réseaux et Société (Paris: PUF, 2003). About Musso, see José L. Garcia, ed., Pierre Musso and the Network Society: From Saint-Simonianism to the Internet (Cham: Springer, 2016).

${ }^{17}$ James W. Carey and John J. Quirk, "The Mythos of Electronic Revolution," in Communication as Culture. Essays on Media and Society, Rev. Ed. (New York: Routledge, 2009); James W. Carey and John J. Quirk, "The History of the Future," in Communication as Culture. Essays on Media and Society. Rev. Ed. (New York: Routledge, 2009).

${ }^{18}$ Jefferson D. Pooley, James W. Carey and Communication Research: Reputation at the University's Margins (New York: Peter Lang, 2016), 65.

${ }^{19}$ Langdon Winner, "Mythinformation," in The Whale and Reactor: A Search for Limits in an Age of High Technology (Chicago: University of Chicago Press, 1989).

${ }^{20}$ Vincent Mosco, The Digital Sublime: Myth, Power, and Cyberspace (Cambridge, MA: MIT Press, 2004).

${ }^{21}$ Lucien Sfez, Technique et Idéologie. Un Enjeu de Pouvoir (Paris: Le Seuil, 2002).

${ }^{22}$ Armand Mattelart, Histoire de l'Utopie Planétaire: De la Cité Prophétique à la Société Globale (Paris: PUF, 1999). 
to mobilize. They have shown us how many new technologies of the past have fallen very short of the unreasonable expectations that were placed on them, how they failed in their promises of achieving a promising future for all of humanity, bringing instead new plagues to our societies: mass manipulation, symbolic violence, incentive to consumerism, addictive behaviors, simulacra, and loss of meaning.

In conclusion: Refusing the naive paths of denying technology or enthusiastically embracing it, is it not imperative to study how media technologies and modes of communication and our social aspirations have been articulated? In order to answer this question, this text proposes that the field (1) should be more attendant to the explicit (and often implicit) views of technology contained in past media scholarship; and (2) should broaden our understanding of what counts as "history of media studies" to include the corpus of work by philosophers of technology.

\section{Bibliography}

Anders, Günther. "The World as Phantom and as Matrix." Dissent 3, no.1 (1956), 14-24.

Borgmann, Albert. Holding On to Reality: The Nature of Information at the Turn of the Millennium. Chicago: University of Chicago Press, 1999.

Breton, Philippe. L'Utopie de la Communication. L'Émergence de l'Homme sans Intérieur. Paris: La Découverte, 1992.

Cardon, Dominique. À Quoi Rêvent les Algorithmes. Nos Vies à l'Heure des Big Data. Paris: Seuil, 2015.

Carey, James W. "Afterword: The Culture in Question." In James W. Carey. A Critical Reader. Edited by Eve Stryker Munson and Catherine A. Warren, 308-339. Minneapolis: University of Minnesota Press, 1997.

—. "Technology and Ideology: the Case of the Telegraph." In Communication as Culture. Essays on Media and Society. Revised Edition, 155-77. New York: Routledge, 2009.

Carey, James W., and John J. Quirk. "The Mythos of Electronic Revolution." In Communication as Culture. Essays on Media and Society. Revised Edition, 87-108. New York: Routledge, 2009.

- "The History of the Future." In Communication as Culture. Essays on Media and Society. Revised Edition, 133-54. New York: Routledge, 2009.

Castells, Manuel. The Information Age: Economy, Society, and Culture. Oxford: Blackwell, 1996, 1997, 1998.

Flichy, Patrick. Une Histoire de la Communication Moderne. Espace Public et Vie Privée. Paris: La Découverte, 1991.
23 Philippe Breton, L'Utopie de la Communication. L'Émergence de l'Homme sans Intérieur (Paris: La Découverte, 1992).

${ }^{24}$ Patrick Flichy, Une Histoire de la Communication Moderne. Espace Public et Vie Privée (Paris: La Découverte, 1991).

25 Dominique Cardon, À Quoi Rêvent les Algorithmes. Nos Vies à l'Heure des Big Data (Paris: Seuil, 2015).

${ }^{26}$ Manuel Castells, The Information Age: Economy, Society, and Culture (Oxford: Blackwell, 1996, 1997, 1998).

27 Pierre Levy, L'Intelligence Collective. Pour une Anthropologie du Cyberespace (Paris: La Découverte, 1994). 
Garcia, José L., ed. Pierre Musso and the Network Society: From SaintSimonianism to the Internet. Cham: Springer, 2016.

Geertz, Clifford. The Interpretation of Cultures. New York: Basic Books, 1973.

Innis, Harold A. Empire and Communications. Toronto: University of Toronto Press, 1970.

- The Bias of Communication. Toronto: University of Toronto Press, 1999.

Kittler, Friedrich A. Gramophone, Film, Typewriter. Stanford, CA: Stanford University Press, 1999.

Levy, Pierre. L'Intelligence Collective. Pour une Anthropologie du Cyberespace. Paris: La Découverte, 1994.

Pooley, Jefferson D. James W. Carey and Communication Research: Reputation at the University's Margins. New York: Peter Lang, 2016.

Manuel, Frank E. The Prophets of Paris. New York: Harper Torchbooks, 1962.

Manuel, Frank E., and Fritzie P. Manuel. Utopian Thought in the Western World. Cambridge, MA: Harvard University Press, 1979.

Marx, Leo. "The Domination of Nature and the Redefinition of Progress." In Progress: Fact or Illusion, edited by Leo Marx and Bruce Mazlish, 201-18. Ann Arbor: University of Michigan Press, 1996.

- The Machine in the Garden. Technology and the Pastoral Ideal in America. Oxford: Oxford University Press, 2000.

Mattelart, Armand. Histoire de l'Utopie Planétaire: De la Cité Prophétique à la Société Globale. Paris: PUF, 1999.

Mitcham, Carl. Thinking through Technology: The Path between Engineering and Philosophy. Chicago: University of Chicago Press, 1994.

Mosco, Vincent. The Digital Sublime: Myth, Power, and Cyberspace. Cambridge, MA: MIT Press, 2004.

Musso, Pierre. Télécommunications et Philosophie des Réseaux. Paris: PUF, 1997.

- Critique des Réseaux. Paris: PUF, 2003.

- dir. Réseaux et Société. Paris: PUF, 2003.

Rakow, Lana, ed. "Philosophy of Technology: Who is in the Saddle?" (Invited Forum). Journalism \& Mass Communication Quarterly 96, no. 2 (2019), 351-66. https://doi . org/10. 1177\%2F1077699019841380.

Sfez, Lucien. Technique et Idéologie. Un Enjeu de Pouvoir. Paris: Le Seuil, 2002.

Subtil, Filipa. "Du Télégraphe à Internet: Enjeux Politiques liés au Technologies de l'Information." In La Contribution en Ligne. Pratiques Participatives à l'Ére du Capitalisme Informationnel, edited by Serge Proulx, José L. Garcia, and Lorna Heaton, 115-125. Montreal: Les Presses d'Université du Québec, 2014. 
Winner, Langdon. The Whale and the Reactor: A Search for Limits in an Age of High Technology. Chicago: University of Chicago Press, 1989.

- Autonomous Technology: Technics-out-of Control as a Theme in Political Thought. Cambridge: MIT Press 1978.

Acknowledgements: The author would like to thank the editors for their attentive reading, comments, and suggestions.

Funding: This work is financed by Portuguese national funds through FCT-Foundation for Science and Technology, through the scope of the project $\operatorname{Ref}^{a}$ UIDB/05021/2020.

History of Media Studies, vol. 1, 2021 